Non-breeding birds seemed to be everywhere and on one occasion a flock of 13 was seen coursing the tundra. It is significant that both lemming and breeding shorebird populations were very much lower in numbers from the 1966 nesting period. It was also noted that both Snowy Owls and Rough-legged Hawks were rare in the 1967 season, yet both nested in 1966. It appears from these observations that in late seasons and when lemming and shorebird populations are low jaegers do not breed.

Arctic vertebrate populations typically fluctuate greatly in numbers. Pitelka (1959) has commented on variations in shorebird populations at Barrow, Alaska and Pitelka, Tomich and Treichel (1955) have discussed the relationship of jaegers and owls to the brown lemming population at
Barrow. Non-breeding of Long-tailed Jaegers in a year following a lemming high was reported in northeast Greenland by Manniche (1910).

\section{Literature Cited}

Manniche, A. L. V. 1910. The terrestrial mammals and birds of northeast Greenland. Danmark Eksped. til Gonlands Nordostkyst 1906-1908. 5 (1) : 1-200.

Pitelka, F. A. 1959. Numbers, breeding schedule, and territoriality in pectoral sandpipers of northern Alaska. The Condor, 61 (4) : 233264.

Pitelka, F. A., P. Q. Tomich and G. W. Treichel. 1955. Ecological relations of jaegers and owls as lemming predators near Barrow, Alaska. Ecol. Monog., 25: 85-117.

\title{
ANNUAL MAY DAY BIRD COUNT, SASKATOON
}

\section{by J. F. Roy, 120 Maple St., Saskatoon}

This year, 42 observers in eight parties established a record of 146 species, one more than on May 27, 1967, when 29 observers recorded 145 species. The early morning birding was best. By 10 a.m. a strong SSE wind had sprung up, and for the rest of the day the wind ranged from 20 to 30 miles per hour. Temperatures ranged from $47^{\circ}$ at 5 a.m. to a high of $74^{\circ}$. The sky was clear at first, becoming partially clouded in the afternoon with widely scattered showers. Observers drove a total of 1178 partymiles and logged 43 party-miles on foot.

The area covered in the annual May count is a square block consisting of 100 townships $(3,600$ square miles $)$ centering on Saskatoon. Obviously, complete coverage of an area this size is impossible, but we are refining our techniques in an attempt to cover representative sections of all types of habitat, in addition to canvassing every major slough, lake and reservoir in the region. As usual, the area was divided into quadrants but this year, for the first time, we had enough participants to field eight separate parties. Among the innovations was an attempt to count all individuals of 18 common species: Mallard, Coot, Willet, Marbled Godwit, Franklin's Gull, Black Tern, Rock Dove, Eastern Kingbird, Western Kingbird, Magpie, Crow, Mountain Bluebird, Loggerhead Shrike, Yellow Warbler, Western Meadow lark, Yellow-headed Blackbird, Red-winged Blackbird, and Clay-colored Sparrow. In addition, all individuals of every other species were counted until a total of 25 was reached; beyond that number, flocks of 50 or more were recorded. To facilitate counting, we prepared two sheets, both listing birds in alphabetic order rather than in A.O.U. sequence. Further changes may be introduced next year. In all likelihood, we will record total numbers only for those species readily observable from a moving car or gathered in large flocks on bodies of water. The idea is to increase our knowledge of changes in bird popula- 
tion from year to year without, at the same time, making the count so demanding that participants have to forego the pleasure of a day afield in the attempt to record every one of the thousands of birds that flit across their field of vision. After ten hours, even the most ardent bird-watcher gets a little exasperated adding yet another Yellow Warbler or Claycolored Sparrow to the list!

Among the highlights of this year's count were Jim Hogg's discovery of the nest of a Common Snipe in the SE quadrant, a new breeding record for Saskatoon; a record number of 137 Buff-breasted Sandpipers, observed in three of the four quadrants; a single Forster's Tern at Pike Lake; a Redheaded Woodpecker in the SE quadrant; a total of 210 Lark Buntings, indicating the second influx in ten years of a normally u ncommon species; and five McCown's Longspurs, a species first recorded in the Saskatoon area in 1967. The warbler count was particularly disappointing, only nine species being observed. It appears to be an off-year for owls as well: only one Burrowing, one Longeared, and one Short-eared Owl were reported. Despite the late date, no Black - billed Cuckoos, Nighthawks, Red-eyed Vireos, or Goldfinches were recorded. Both Cedar Waxwings and Long-billed Marsh Wrens were seen on the day following the count.

\section{Species by region for Annual May Day Count, Saskatoon, May 25, 1968}

Compiled by A. L. Nijssen and W. S. Richards

\begin{tabular}{lccccc} 
& Grand & \multicolumn{3}{c}{ Quadrant Totals } \\
Species & Total & Sw & NW & NE & SE \\
Red-nk Grebe & 2 & $\mathrm{x}$ & & & $\mathrm{x}$ \\
Horned Grebe & $107+$ & $\mathrm{x}$ & $\mathrm{x}$ & $\mathrm{x}$ & $\mathrm{x}$ \\
Eared Grebe & 50 & $\mathrm{x}$ & $\mathrm{x}$ & $\mathrm{x}$ & $\mathrm{x}$ \\
West Grebe & 12 & $\mathrm{x}$ & & $\mathrm{x}$ & $\mathrm{x}$ \\
Pied-b Grebe & 17 & $\mathrm{x}$ & $\mathrm{x}$ & $\mathrm{x}$ & $\mathrm{x}$ \\
Dc Cormorant & 6 & $\mathrm{x}$ & & & $\mathrm{x}$ \\
Gr Bl Heron & 2 & & $\mathrm{x}$ & & $\mathrm{x}$ \\
Am Bittern & $5+$ & $\mathrm{x}$ & & $\mathrm{x}$ & $\mathrm{x}$ \\
Wh Swan & 3 & $\mathrm{x}$ & & & \\
C Goose & 3 & $\mathrm{x}$ & & & $\mathrm{x}$ \\
* Mallard & 671 & $\mathrm{x}$ & $\mathrm{N}$ & $\mathrm{N}$ & $\mathrm{x}$ \\
Gadwall & $143+$ & $\mathrm{x}$ & $\mathrm{x}$ & $\mathrm{x}$ & $\mathrm{x}$
\end{tabular}

Species

Grand Quadrant Totals

Pintail

Gr-wgd Teal

Bl-wgd Teal

Am Widgeon

Shoveler

Redhead

Ring-nk Duck

Canvasback

Lesser Scaup

C Goldeneye

Bufflehead

Wh-wg Scoter

Ruddy Duck

Cooper Hawk

R-tail Hawk

Swains Hawk

Marsh Hawk

Pigeon Hawk

Sparrow Hawk

Ruffed Grouse

Sh-t Grouse

R-n Pheasant

Gray Part

Sora

*Am Coot

Semipal Plov

Killdeer

Gldn Plover

Bl-b Plover

$\mathrm{Ru}$ Turnstone

C Snipe

L-b Curlew

Upland Plover

Spot Sandp

*Willet

Lesser Ylegs

Knot

Pector Sandp

Wh-r Sandp

Baird Sandp

Least Sandp

Dowitcher

Stilt Sandp

Semipa Sandp

Buff-b Sandp

*Marbl Godwit

Sanderling

Am Avocet

Wils Phalar

$\mathrm{N}$ Phalarope $2,403+\mathrm{x}$

Herring Gull

Calif Gull

Ring-b Gull

*Frank Gull
Total SW NW NE SE

$294+\mathrm{x} \quad \mathrm{x} \quad \mathrm{x} \quad \mathrm{x}$

$51+\mathrm{x} \quad \mathrm{x} \quad \mathrm{x}$ x

$220+\mathrm{x} \quad \mathrm{x} \quad \mathrm{x} \quad \mathrm{x}$

$241+\mathrm{x} \quad \mathrm{x} \quad \mathrm{x} \quad \mathrm{x}$

$306+\mathrm{x} \quad \mathrm{x} \quad \mathrm{x} \quad \mathrm{x}$

$109+\mathrm{x} \quad \mathrm{x} \quad \mathrm{x} \quad \mathrm{x}$

$4 x \quad x \quad x$

$267+\mathrm{x} \quad \mathrm{N} \quad \mathrm{x} \quad \mathrm{x}$

$91+\mathrm{x} \quad \mathrm{x} \times$

$11 \mathrm{x}$

$8 \quad \mathrm{x} \quad \mathrm{x} \quad \mathrm{x}-\mathrm{x}$

$133+\mathrm{x} \quad \mathrm{x} \quad \mathrm{x} \quad \mathrm{x}$

$\begin{array}{llllllllllll}3 & \mathrm{x} & \mathrm{x} & \mathrm{x}\end{array}$

$\begin{array}{lllll}8 & \mathrm{x} & \mathrm{N} & \mathrm{x} & \mathrm{x}\end{array}$

$\begin{array}{lllll}14 & \mathrm{x} & \mathrm{x} & \mathrm{x} & \mathrm{x}\end{array}$

$\begin{array}{lllll}53 & \mathrm{x} & \mathrm{x} & \mathrm{x} & \mathrm{x}\end{array}$

$3 \quad x$

$5 \mathrm{x}$

$\begin{array}{lllll}6 & \mathrm{x} & \mathrm{x} & \mathrm{x}\end{array}$

$\begin{array}{lllll}19 & \mathrm{x} & \mathrm{N} & \mathrm{x} & \mathrm{x}\end{array}$

$\begin{array}{lllll}31 & x & x & x & x\end{array}$

$2,307+\mathrm{x} \quad \mathrm{x} \quad \mathrm{x} \quad \mathrm{N}$

$7 \quad x \quad x$

$90 \times \mathrm{N} \quad \mathrm{x} \quad \mathrm{x}$

$103 \times x \quad x \quad x$

10

26

60

11

$32+$

$82+$

$55+$

$207+$

$117+\mathrm{x}$

7

$529+$

137

$100 \pm \mathrm{x}$

$117+$

$170+\mathrm{N}$

$165+x$$$
\mathrm{X}
$$ 